\title{
PENGARUH FAKTOR INTERNAL DAN FAKTOR EKSTERNAL TERHADAP KEPUTUSAN PEREMPUAN BERWIRAUSAHA
}

\author{
Oleh:
}

\author{
Yuridistya Primadhita'), Susilowati Budiningsih²), Anggraita Primatami' \\ Sekolah Tinggi Ilmu Ekonomi IPWI Jakarta1,2,3) \\ yuridistya_dhita@yahoo.com ${ }^{1}$; susilowatisubud@gmail.com ${ }^{2}$; anggraitami@gmail.com $^{3)}$
}

\begin{abstract}
ABSTRAK
Penelitian ini bertujuan untuk mengetahui faktor internal dan faktor eksternal yang mempengaruhi keputusan perempuan berwirausaha di Kecamatan Cilandak, Jakarta Selatan.

Faktor internal meliputi keyakinan diri, keahlian, dan motivasi diri, sedangkan faktor eksternal meliputi lingkungan keluarga, lingkungan sosial, dan toleransi risiko.

Data yang digunakan adalah data primer dari kuisioner kepada 100 responden perempuan wirausaha.

Hasil penelitian menunjukan bahwa faktor internal dan faktor eksternal masing-masing berpengaruh terhadap keputusan perempuan berwirausaha. Faktor internal dan faktor eksternal dalam menjelaskan keputusan perempuan berwirausaha adalah sebesar 67,9\%.
\end{abstract}

Kata kunci:

Faktor internal, faktor eksternal, keputusan berwirausaha, perempuan

\section{PENDAHULUAN}

Data Kementerian Koperasi dan UKM tahun 2015 menyebutkan bahwa dari jumlah pelaku UMKM di Indonesia yang berjumlah sekitar 52 juta, sebanyak 60\% usaha dijalankan oleh perempuan. Perempuan masih mendominasi usaha kecil hingga menengah dibandingkan dengan usaha besar. Para pelaku usaha perempuan ini tidak banyak yang berada pada usaha dengan skala besar atau modern karena usaha skala besar dan modern cenderung masih didominasi oleh pelaku usaha pria. Perempuan wirausaha skala UMKM ini lebih banyak berada dalam kelompok usaha manufaktur, tekstil, pakaian jadi, serta makanan dan minuman dengan proses produksi yang cenderung sederhana (Tambunan, 2012). Pelaku usaha perempuan ini terdiri dari berbagai tingkatan usia, pendidikan, suku, sektor usaha, dan sebagainya. Umumnya, orang mengenal pelaku usaha perempuan adalah perempuan yang memiliki aktivitas ganda, sebagai pelaku usaha dan juga sekaligus adalah ibu rumah tangga yang mengurus keluarga. Namun demikian, saat ini banyak perempuan yang belum menikah dan berusia muda sudah mulai menekuni dunia usaha meskipun dalam taraf awal.

Penelitian terdahulu mengenai pelaku usaha perempuan di beberapa negara berkembang di Asia menemukan bahwa 
setidaknya terdapat tiga alasan perempuan memilih untuk melakukan usaha sebagai berikut (Tambunan, 2009:33):

1. Perempuan berwirausaha karena adanya kesempatan, misalnya meneruskan hobi, mengikuti pasangan, dan memanfaatkan waktu luang.

2. Perempuan berwirausaha karena menghadapi kondisi tertentu yang mengharuskan perempuan berwirausaha, misalnya karena membutuhkan uang, tertantang melakukan sesuatu, dan sebagai pembuktian pada orang lain jika ia mampu melakukan sesuatu.

3. Perempuan berwirausaha karena dengan sukarela dan sengaja memilih profesi wirausaha untuk kepuasan diri, mandiri, dan sebagai contoh untuk anak-anak.

Dari ulasan tersebut di atas, alasan perempuan berwirausaha dapat muncul dari berbagai motif dan situasi. Penelitianpenelitian di Indonesia yang berfokus pada wirausaha perempuan menemukan bahwa terdapat faktor internal dan faktor eksternal yang dapat mempengaruhi minat perempuan berwirausaha. Salah satunya penelitian Aimasari dan Ghina (2015: 2795) yang meneliti mengenai faktor-faktor yang memotivasi wirausaha perempuan di Kota Bandung. Hasil penelitian menyimpulkan bahwa faktor yang dapat motivasi wirausaha perempuan terbagi ke dalam lima kelompok besar yaitu personal growth (pengembangan diri), family (keluarga) dan income-job (pendapatan), government subsidy (subsidi pemerintah) dan skill and knowledge (keahlian dan pengetahuan). Hasil tersebut membuktikan bahwa alasan perempuan untuk berwirausaha dapat berasal dari dalam dirinya maupun dari pihak lain atau situasi di lingkungan sekitar. Berdasarkan kondisi tersebut, maka penelitian ini akan menganalisis faktor internal dan faktor eksternal yang mempengaruhi keputusan perempuan untuk berwirausaha di Kecamatan Cilandak, Jakarta Selatan.

\section{TUJUAN PENELITIAN}

Penelitian ini dilakukan dengan tujuan mengatahui pengaruh faktor internal dan faktor eksternal terhadap keputusan perempuan berwirausaha di Kecamatan Cilandak, Jakarta Selatan.

\section{TELAAH LITERATUR DAN PENGEMBANGAN HIPOTESIS}

Menurut Barani dan Dheepa (2013:25), wirausaha perempuan dapat didefinisikan sebagai wanita atau sekelompok wanita yang memulai, mengatur dan mengoperasikan perusahaan bisnis, baik dalam skala kecil atau rumahan maupun dalam skala besar. Keberhasilan wirausaha perempuan akan ditentukan oleh berbagai faktor baik yang berasal dari dalam diri maupun faktor dari orang lain dan lingkungan sekitar.

\section{Faktor Internal}

Bandura (2001:8) menyatakan bahwa keyakinan diri sebagai salah satu faktor penting keberhasilan seseorang berwirausaha. Mereka yang memiliki keyakinan diri yang tinggi cenderung berpikir positif dan memandang tantangan sebagai suatu peluang yang dapat diatasi dengan kompetensi dan upaya yang dimiliki. Sementara itu, dikatakan oleh Aimasari dan Ghina (2015:2798) bahwa para wirausaha perempuan harus memiliki faktor keahlian dalam memulai dan menjalankan usahanya. Keahlian dalam berwirausaha didefinisikan tidak hanya mencakup penilaian terhadap diri sendiri bahwa ia mampu berwirausaha, melainkan juga penilaian dari orang lain atau 
masyarakat terhadap kemampuannya. Keahlian ini juga mencakup kemampuan untuk bisa mendapatkan tambahan modal dan pinjaman usaha. Faktor lain yang tidak kalah penting menurut Pristiana dkk (2009:55-56) adalah motivasi karena dapat menyebabkan perilaku seseorang mau bekerja giat dan antusias dalam mencapai hasil. Motivasi berwirausaha bagi perempuan dapat didasarkan pada kebutuhan akan aktualisasi diri sendiri yang ingin memaksimalkan potensi diri, pengembangan diri semaksimal mungkin, kreativitas, ekspresi diri, dan melakukan apa yang paling cocok bagi dirinya.

\section{Faktor Eksternal}

Nurudin (2017:332) menyatakan bahwa salah satu faktor di luar diri sendiri yang berperan dalam pengambilan keputusan perempuan berwirausaha adalah lingkungan keluarga. Hal ini dikarenakan lingkungan keluarga merupakan lingkungan pertama untuk belajar dan menerima bimbingan dari orang tua atau anggota keluarga lainnya, akibatnya minat perempuan sebagai wirausaha akan semakin besar manakala orang tua atau anggota keluarga lain juga berprofesi sebagai wirausaha. Selain keluarga, lingkungan sosial seperti teman atau tetangga yang sebagian besar berwirausaha juga menyebabkan perempuan lebih berminat untuk berwirausaha. Dalam lingkungan sosial terjadi interaksi yang dapat mengarah kepada penyeragaman persepsi akan suatu hal yang dianggap baik atau buruk. Jika dirasa wirausaha adalah sesuatu hal yang positif di dalam presepsi masyarakat sekitar maka akan berdampak pada meningkatnya kecenderungan untuk berwirausaha. Hal yang tidak kalah penting adalah faktor toleransi akan risiko. Risiko yang dapat dialami wirausaha setidaknya terbagi dalam enam risiko yaitu risiko produksi, risiko pemasaran, risiko keuangan, risiko permintaan pasar, risiko perbaikan, dan risiko kerjasama.

\section{Pengaruh Faktor Internal dan Eksternal terhadap Keputusan Perempuan Berwirausaha}

Keputusan perempuan untuk berwirausaha dapat dipengaruhi oleh berbagai alasan. Penelitian Pristiana dkk (2009:52) mengenai pengambilan keputusan wanita berwirausaha di Kota Surabaya menemukan bahwa faktor internal seperti motivasi berprestasi, keyakinan diri, dan sikap wirausaha berpengaruh terhadap pengambilan keputusan perempuan menjadi wirausaha. Sedangkan faktor eksternal seperti toleransi akan risiko, lingkungan keluarga, dan lingkungan sosial juga mempengaruhi pengambilan keputusan perempuan untuk berwirausaha. Semakin banyak faktor pendukung yang mempengaruhi perempuan untuk berwirausaha, maka akan semakin memperbesar peluang perempuan untuk mengambil keputusan berwirausaha.

Aimasari dan Ghina (2015:2795) melakukan penelitian mengenai faktorfaktor yang memotivasi wirausaha perempuan di Kota Bandung. Hasil penelitian terhadap 100 responden wirausaha wanita menunjukan bahwa faktor yang memotivasi perempuan untuk berwirausaha dapat dikelompokan menjadi lima faktor yaitu personal growth (pengembangan diri), family (keluarga), income-job (pendapatan), government subsidy (subsidi pemerintah), dan skill and knowledge (Keahlian dan Pengetahuan). Dari lima kelompok tersebut, faktor yang paling dominan dalam memotivasi pengusaha wanita untuk berwirausaha adalah faktor income-job (pendapatan) dengan nilai varians paling tinggi 
dibandingkan dengan faktor-faktor lainnya.

Nurudin (2017:335) dalam penelitiannya mengenai pengaruh faktor internal berupa minat dan faktor eksternal berupa lingkungan keluarga terhadap keputusan perempuan muslim berwirausaha di Kecamatan Bonang, Kabupaten Demak menemukan bahwa faktor minat berpengaruh signifikan terhadap keputusan perempuan muslim berwirausaha, begitu pula faktor lingkungan keluarga yang memiliki pengaruh signifikan terhadap keputusan perempuan muslim berwirausaha. Jika orang tua atau keluarga dekat memiliki usaha, maka akan menyebabkan semakin tingginya minat perempuan untuk berwirausaha.

\section{Rerangka Penelitian}

Dari uraian di atas, maka dugaan sementara yang dapat diambil adalah:

1. H1: Faktor internal (keyakinan diri, keahlian, dan motivasi diri) berpengaruh signifikan terhadap keputusan perempuan berwirausaha di Kecamatan Cilandak, Jakarta Selatan.

2. H2: Faktor eksternal (lingkungan keluarga, lingkungan sosial, dan toleransi risiko) berpengaruh signifikan terhadap keputusan perempuan berwirausaha di Kecamatan Cilandak, Jakarta Selatan.

Berdasarkan hipotesis di atas, model penelitian yang dipakai dalam penelitian ini dapat digambarkan dalam kerangka pikir sebagai berikut:
Gambar 1

Kerangka Pemikiran Penelitian

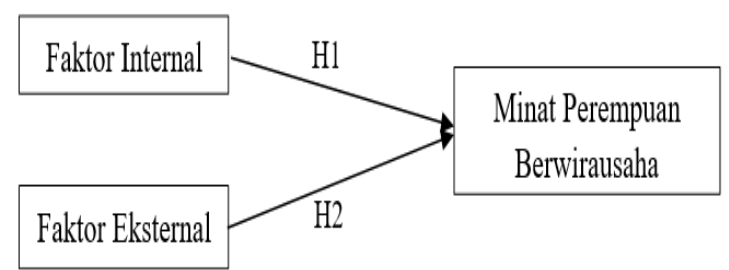

Sumber: konsep penelitian penulis, 2018

\section{METODE PENELITIAN \\ Sampel Penelitian}

Objek penelitian ini adalah perempuan yang memiliki usaha UMKM di Kecamatan Cilandak, Kota Jakarta Selatan. Subjek penelitian ini mencakup wirausaha perempuan yang memiliki dan menjalankan usaha antara lain di bidang kuliner, warung, toko sembako, pakaian jadi, souvenir, toko kelontong, fotocopy, laundry, dan lain sebagainya di Kecamatan Cilandak, Kota Jakarta Selatan. Penelitian ini dilakukan dari Bulan September hingga November 2018. Pengambilan sampel terdiri atas 100 responden dengan menggunakan teknik Non-Probability Sampling. Teknik Non-Probability Sampling yaitu semua elemen dalam populasi tidak memiliki kesempatan yang sama untuk dipilih menjadi sampel (Sugiyono, 2007). Hal ini dilakukan karena adanya keterbatasan waktu penelitian. 100 responden tersebut diminta untuk mengisi kuisioner yang sudah disiapkan. Data primer yang berasal dari kuisioner tersebut kemudian diolah dan dianalisis untuk melihat hubungan dan pengaruh variabelvariabel independen berupa faktor internal dan faktor eksternal terhadap variabel dependen berupa keputusan perempuan berwirausaha. 


\section{Operasionalisasi Variabel}

Variabel yang digunakan dalam penelitian ini meliputi faktor internal dan faktor eksternal sebagai variabel independen, sedangkan keputusan perempuan berwirausaha digunakan sebagai variabel dependen. Rincian variabel independen dan dependen yang dipakai dalam penelitian adalah sebagai berikut:

Tabel 1

Operasional Variabel Penelitian

\begin{tabular}{|c|c|c|}
\hline Variabel dan Definisi & Indikator & Referensi \\
\hline $\begin{array}{l}\text { Faktor Internal }\left(X_{1}\right) \\
\text { - Hal-hal yang berasal dari } \\
\text { dalam diri sendiri. } \\
\end{array}$ & $\begin{array}{l}\text { 1. Keyakinan Diri } \\
\text { 2. Keahlian } \\
\text { 3. Motivasi Diri } \\
\end{array}$ & $\begin{array}{l}\text { Aimasari dan Ghina } \\
\text { (2015), Priastiani (2009). }\end{array}$ \\
\hline $\begin{array}{l}\text { Faktor Eksternal }\left(\mathrm{X}_{2}\right) \\
\text { - Hal-hal yang bersumber } \\
\text { dari pihak lain di luar diri } \\
\text { sendiri. }\end{array}$ & $\begin{array}{l}\text { 1. Lingkungan Keluarga } \\
\text { 2. Lingkungan Sosial } \\
\text { 3. Toleransi Risiko }\end{array}$ & $\begin{array}{l}\text { Aimasari dan Ghina } \\
\text { (2015), Nurudin (2017), } \\
\text { Priastiani (2009). }\end{array}$ \\
\hline $\begin{array}{l}\text { Keputusan Perempuan } \\
\text { Berwirausaha (Y) } \\
\text { - Menentukan pilihan dan } \\
\text { mengambil tindakan } \\
\text { untuk mulai menjalankan } \\
\text { usaha. }\end{array}$ & $\begin{array}{l}\text { 1. Ketertarikan untuk } \\
\text { Berwirausaha } \\
\text { 2. Kemauan Menjalankan Usaha } \\
\text { 3. Kesenangan Setelah } \\
\text { Berwirausaha }\end{array}$ & $\begin{array}{l}\text { Aimasari dan Ghina } \\
\text { (2015), Nurudin (2017), } \\
\text { Priastiani (2009). }\end{array}$ \\
\hline
\end{tabular}

Sumber: konsep penelitian penulis, 2018

\section{Metode Analisis Data}

Tujuan melakukan analisis data adalah untuk mendapatkan informasi akurat yang terdapat di dalam data penelitian. Langkah awal yang dilakukan dalam penelitian ini adalah pengumpulan data primer berupa kuisioner. Pilihan jawaban menggunakan teknik skala likert yang menggolongkan jawaban ke dalam lima skala (Sugiyono, 2007). Hasil dari kuisioner selanjutnya diolah dengan program SPSS (Statistical Package for Social Science) menjadi empat tahap. Pertama, dilakukan uji reliabilitas dan uji validitas. Hasil kuisioner dikatakan reliable jika jawaban pertanyaan konsisten dari waktu ke waktu. Suatu variabel dikatakan reliable jika nilai Cronbach Alpha $(\alpha)>0,6$. Sementara untuk uji validitas, data dikatakan valid jika indikator penelitian memiliki korelasi antara skor masing-masing indikator terhadap skor totalnya (Sugiyono, 2007).

Kedua, dilakukan uji asumsi klasik berupa uji multikolineritas, uji heteroskedastis, dan uji normalitas. Uji multikolinearitas dilakukan untuk melihat apakah ditemukan adanya korelasi antar variabel bebas, uji heteroskedastis dilakukan untuk mengetahui apakah varians berubah dari observasi ke observasi, dan uji normalitas dilakukan untuk mengetahui apakah variabelvariabel yang digunakan dalam suatu model regresi telah berdistribusi normal atau mendekati normal. Sementara itu, uji autokorelasi tidak dilakukan dalam penelitian dengan data kuisioner karena pengukuran semua variabel dilakukan pada saat bersamaan atau dalam satu periode waktu (Ariefianto, 2012).

Ketiga, dilakukan analisis regresi linier berganda guna melihat pengaruh variabelvariabel bebas (independen) terhadap variabel independen, yang dilakukan dengan melihat koefisien determinasi (R2) dan adjusted $R 2$, serta menilai berdasarkan nilai statistik pada uji F dan uji t. Nilai R2 pada intinya mengukur seberapa jauh kemampuan sebuah model menerangkan variasi variabel dependen. Namun, R2 dapat menjadi bias karena setiap penambahan satu variabel independen, maka R2 pasti meningkat tidak peduli apakah variabel tersebut berpengaruh signifikan terhadap variabel dependen atau tidak. Penelitian ini menggunakan nilai adjusted R2 dengan tujuan agar tidak bias dalam mengukur kemampuan model dalam menerangkan variasi variabel dependen. Nilai adjusted R2 dapat naik atau turun apabila satu variabel independen ditambahkan ke dalam model (Ariefianto, 2012).

Keempat, dilakukan uji $F$ dan uji parsial (uji t). Uji F digunakan untuk mengetahui tingkat siginifikansi kelayakan 
model yang menunjukkan kemampuan model dalam menjelaskan pengaruh variabel-variabel independen secara bersama-sama (simultan) terhadap variabel dependen. Sedangkan uji $t$ digunakan untuk mengetahui seberapa jauh pengaruh satu variabel independen secara individual dapat menerangkan variasi variabel dependen (Ariefianto, 2012).

Adapun model regresi berganda dalam penelitian ini adalah sebagai berikut:

$$
Y=\beta 0+\beta 1 X 1+\beta 2 X 2
$$

Dimana:

- $\mathrm{Y}=$ Keputusan perempuan berwirausaha

- $\beta 0=$ Konstanta

- $\quad \beta 1, \beta 2=$ Koefisien regresi

- $\mathrm{X} 1=$ Faktor internal

- $\mathrm{X} 2$ = Faktor eksternal

\section{HASIL DAN PEMBAHASAN Karakteristik Responden}

Berdasarkan kuisioner yang diperoleh, diketahui bahwa dari 100 orang total responden, sebagaian besar berusia 40 - 50 tahun $(63 \%)$ dengan pendidikaan formal terbesar SMU/sederajat (56\%). Sebagian besar memutuskan berwirausaha karena dorongan faktor ekonomi keluarga (74\%) dengan sektor usaha yang digeluti mayoritas adalah jenis usaha kuliner (53\%) dengan rata-rata lama usaha yang telah dirintis mayoritas selama 5 - 10 tahun (58\%) dan profit yang diperoleh responden selama satu bulan mayoritas antara Rp 5 juta - 10 juta (49\%).

\section{Uji Validitas dan Reliabilitas}

Hasil pengujian validitas dan reliabilitas menunjukan bahwa secara keseluruhan pernyataan pada masingmasing indikator variabel faktor internal, faktor eksternal, dan keputusan perempuan berwirausaha dapat digunakan dalam penelitian, karena telah valid dan reliabel. Hal ini ditunjukan dengan nilai corected item-total correlation untuk semua butir pernyataan pada setiap variabel memperoleh lebih besar dari 0,2 dan nilai alpha-cronbach untuk setiap variabel lebih besar dari 0,7.

\section{Pengujian Asumsi Klasik}

Hasil pengujian asumsi klasik menunjukan bahwa tidak terjadi pelanggaran asumsi klasik, dimana telah terpenuhi asumsi normalitas, tidak terjadi heteroskedastisitas, dan tidak terjadi multikolinearitas. Dalam pengujian asumsi normalitas dengan Uji KolmogorovSmirnov diketahui bahwa data berdistribusi normal dengan nilai signifikansi lebih besar dari 0,05. Untuk asumsi heteroskedastisitas dengan Uji Glejser menunjukan bahwa tidak terjadi heteroskedastisitas karena nilai signifikansi yang diperoleh lebih besar dari 0,05. Dari hasil pengujian asumsi multikolinearitas diketahui bahwa nilai VIF untuk variabel X1 dan X2 kurang dari $10(2,239<10)$, sehingga tidak terjadi pelanggaran asumsi multikolinearitas.

\section{Uji Kelayakan Model}

Berdasarkan hasil pengujian diketahui bahwa variabel bebas yang digunakan dalam penelitian merupakan penjelas nyata pada variabel terikat. Hal ini ditunjukan dengan signifikansi nilai $F$ hitung lebih kecil dari 0,05. Sehingga model dalam penelitian ini layak untuk digunakan. Sementara itu, besarnya kemampuan variabel bebas dalam menjelaskan variabel terikat adalah sebesar 0,679 atau $67,9 \%$ sedangkan sisanya sebesar 0,321 atau $32,1 \%$ dijelaskan oleh variabel lain yang tidak digunakan dalam penelitian ini. 
Tabel 2

Model Summary Pengaruh Faktor Internal dan Eksternal Terhadap Keputusan

Perempuan Berwirausaha

Model Summary
\begin{tabular}{|l|r|r|r|r|r|}
\hline Model & \multicolumn{1}{|c|}{$R$} & $R$ Square & $\begin{array}{c}\text { Adjusted R } \\
\text { Square }\end{array}$ & $\begin{array}{c}\text { Std. Error of the } \\
\text { Estimate }\end{array}$ & Durbin-Watson \\
\hline 1 & $.828^{8}$ & .686 & .679 & 1.24330 & 2.326 \\
\hline a. Predictors: (Constant), Fl, FE & & & \\
b. DependentVariable: KPB
\end{tabular}

Sumber: output SPSS data diolah, 2018

Tabel 3

Anova Pengaruh Faktor Internal dan

Eksternal Terhadap Keputusan

Perempuan Berwirausaha ANOVA

\begin{tabular}{|c|c|c|c|c|c|}
\hline Model & Sum of Squares & df & Mean Square & $F$ & Sig. \\
\hline 1 Regression & 327.097 & 2 & 163.549 & 105.802 & $.000^{3}$ \\
\hline Residual & 149.943 & 97 & 1.546 & & \\
\hline Total & 477.040 & 99 & & & \\
\hline
\end{tabular}

b. DependentVariable:KPB

Sumber: ouput SPSS data diolah, 2018

\section{Uji Hipotesis}

Hasil pengujian hipotesis parsial didasarkan pada tabel berikut.

Tabel 4

Koefisien Pengaruh Faktor Internal dan

Eksternal Terhadap Keputusan

Perempuan Berwirausaha

Coefficients $^{3}$

\begin{tabular}{|c|c|c|c|c|c|}
\hline \multirow[b]{2}{*}{ Model } & \multicolumn{2}{|c|}{ Unstandardized Coefficients } & \multirow{2}{*}{$\begin{array}{c}\begin{array}{c}\text { Standardized } \\
\text { Coefficients }\end{array} \\
\text { Beta }\end{array}$} & \multirow[b]{2}{*}{$t$} & \multirow[b]{2}{*}{ Sig. } \\
\hline & $B$ & Std. Error & & & \\
\hline $1 \quad$ (Constant) & -.029 & .744 & & .039 & .969 \\
\hline $\mathrm{Fl}$ & .443 & .092 & .410 & 4.817 & .000 \\
\hline $\mathrm{FE}$ & .545 & .098 & .476 & 5.590 & .000 \\
\hline
\end{tabular}

Sumber: output SPSS data diolah, 2018
Pengujian Hipotesis Pengaruh Faktor Internal terhadap Keputusan Perempuan Berwirausaha (H1)

Hipotesis pertama dalam penelitian ini adalah terdapat pengaruh yang signifikan antara faktor internal terhadap keputusan perempuan berwirausaha. Sehingga hipotesis statistiknya adalah sebagai berikut:

H1o : b1 = 0 : tidak ada pengaruh faktor internal terhadap keputusan perempuan berwirausaha

H1a : $b 1 \neq 0$ : ada pengaruh faktor internal terhadap keputusan perempuan berwirausaha

Nilai probabilitas t-hitung variabel faktor internal adalah sebesar 0,000. Sehingga H1o ditolak atau H1a diterima, yang berarti terdapat pengaruh yang signifikan antara faktor internal terhadap keputusan wanita berwirausaha.

\section{Pengujian Hipotesis Pengaruh Faktor Eksternal terhadap Keputusan Perempuan Berwirausaha (H2)}

Hipotesis kedua dalam penelitian ini adalah terdapat pengaruh yang signifikan antara faktor eksternal terhadap keputusan perempuan berwirausaha. Sehingga hipotesis statistiknya adalah sebagai berikut:

$\mathrm{H} 2 \mathrm{o}: \mathrm{b} 2=0$ : tidak ada pengaruh faktor eksternal terhadap keputusan perempuan berwirausaha

$\mathrm{H} 2 \mathrm{a}: \mathrm{b} 2 \neq 0$ : ada pengaruh faktor eksternal terhadap keputusan perempuan berwirausaha

Nilai probabilitas t-hitung variabel faktor eksternal adalah sebesar 0,000 Sehingga H2o ditolak atau H2a diterima, yang berarti terdapat pengaruh yang signifikan antara faktor eksternal terhadap keputusan wanita berwirausaha. 


\section{Pembahasan}

Hasil

penelitian

regresi

memperlihatkan faktor internal dan faktor eksternal berupa keyakinan diri, keahlian, motivasi diri, lingkungan kelurga, lingkungan sosial, dan toleransi risiko berpengaruh signifikan terhadap keputusan perempuan berwirausaha yang ditunjukan dengan nilai $\mathrm{p}$ yang lebih kecil dari 0,05 .

Model persamaan regresi linier ganda $\mathrm{Y}=-0,029+0,443 \mathrm{X} 1+0,545 \mathrm{X} 2$

\section{Pengaruh Faktor Internal terhadap Keputusan Wanita Berwirausaha}

Faktor internal memiliki pengaruh yang signifikan terhadap keputusan wanita berwirausaha dengan arah positif. Besar pengaruh faktor internal terhadap keputusan wanita berwirausaha ditunjukan dengan nilai koefisien regresi faktor internal sebesar 0,443. Semakin besar faktor internal yang dimiliki, berupa keyakinan diri, keahlian, dan motivasi diri, maka semakin besar keputusan perempuan berwirausaha. Hal ini sejalan dengan hasil penelitian Aimasari dan Ghina (2015:2798) yang menunjukan bahwa faktor internal berupa keahlian dan pengembangan diri memiliki pengaruh terhadap motivasi perempuan untuk berwiruasaha. Penelitian ini juga sejalan dengan hasil penelitian Priastiani (2009) yang menyatakan bahwa faktor internal berupa keyakinan diri dan motivasi diri memiliki pengaruh terhadap keputusan perempuan berwirausaha.

Faktor internal berupa keyakinan diri, keahlian, dan motivasi diri dari pemilik usaha berpengaruh signifikan karena dapat mempengaruhi perempuan untuk memutuskan berwirausaha. Perempuan yang memiliki keyakinan diri yang lebih tinggi cenderung berpikir lebih positif. Keyakinan diri ini memunculkan adanya kepercayaan diri, sehingga jika menemukan hambatan atau tantangan dalam berwirausaha, ia akan cenderung lebih mudah menghadapi dan bertahan untuk mengatasi masalah yang ada. Faktor lain yaitu keahlian juga turut mendukung perempuan mengambil keputusan berwirausaha. Keahlian ini mencakup penilaian diri sendiri dan orang lain bahwa ia mampu berwirausaha, serta kemampuan untuk mendapatkan modal usaha. Semakin tinggi keahlian yang dimilikinya tersebut, maka akan meningkatkan keputusan perempuan untuk berwirausaha. Sebagai tambahan, semakin tinggi motivasi perempuana bahwa ia mampu menjalankan usaha juga akan semakin meningkatkan keputusan perempuan berwirausaha. Motivasi berwirausaha ini antara lain didasarkan pada kebutuhan untuk memiliki penghasilan sendiri dan mengembangkan diri sendiri.

\section{Pengaruh Faktor Eksternal terhadap Keputusan Wanita Berwirausaha}

Faktor eksternal memiliki pengaruh yang signifikan terhadap keputusan wanita berwirausaha dengan arah positif. Besar pengaruh faktor eksternal terhadap keputusan wanita berwirausaha ditunjukan dengan nilai koefisien regresi faktor eksternal sebesar 0,545. Semakin besar faktor eksternal yang dimiliki maka semakin besar keputusan wanita berwirausaha. Hal ini sejalan dengan hasil penelitian Aimasari dan Ghina (2015:2798) yang menyatakan bahwa faktor eksternal berupa keluarga memiliki pengaruh terhadap motivasi perempuan berwirausaha. Hasil ini juga sejalan dengan hasil penelitian Nurudin (2017:335) bahwa lingkungan keluarga berpengaruh secara signifikan terhadap minat perempuan berwirausaha. Hal yang sama juga terjadi pada hasil penelitian Priastiani (2009) yang menunjukan bahwa lingkungan keluarga, 
lingkungan sosial, dan toleransi risiko berpengaruh signifikan terhadap keputusan perempuan berwirausaha.

Faktor eksternal berupa lingkungan keluarga, lingkungan sosial, dan toleransi risiko berpengaruh signifikan karena dapat mempengaruhi perempuan untuk memulai berwirausaha. Minat perempuan memutuskan berwirausaha akan semakin besar manakala orang tua atau anggota keluarga lain juga berprofesi sebagai wirausaha. Selain keluarga, lingkungan sosial seperti teman atau tetangga yang sebagian besar berwirausaha juga menyebabkan meningkatnya minat perempuan untuk berwirausaha. Hal yang tidak kalah penting adalah faktor toleransi akan risiko. Setiap pelaku wirausaha akan menghadapi risiko dalam menjalankan usaha. Risiko yang dapat dialami wirausaha antara lain adalah risiko produksi, risiko pemasaran, risiko keuangan, risiko permintaan pasar, risiko perbaikan, dan risiko kerjasama. Jika risiko-risiko tersebut dianggap masih dapat ditoleransi dan dapat dihadapi maka akan cenderung meningkatkan keputusan perempuan dalam berwirausaha.

\section{KESIMPULAN}

Faktor internal dan faktor eksternal secara simultan berpengaruh positif dan signifikan terhadap keputusan perempuan berwirausaha di Kecamatan Cilandak, Jakarta Selatan. Faktor eksternal memiliki pengaruh yang lebih dominan dibandingkan dengan faktor internal. Besarnya kemampuan faktor internal dan faktor eksternal dalam menjelaskan keputusan perempuan berwirausah sebesar $67,9 \%$, sedangkan sisanya sebesar $32,1 \%$ dijelaskan oleh variabel lain yang tidak digunakan dalam penelitian ini.

1. Faktor internal berupa keyakinan diri, keahlian, dan motivasi diri berpengaruh posistif dan signifikan terhadap keputusan perempuan berwirausaha di Kecamatan Cilandak, Jakarta Selatan.

2. Faktor eksternal berupa lingkungan keluarga, lingkungan sosial, dan toleransi risiko berpengaruh positif dan signifikan terhadap keputusan perempuan berwirausaha di Kecamatan Cilandak, Jakarta Selatan.

\section{SARAN}

1. Penelitian ini hanya mengambil responden yang berada di daerah Kecamatan Cilandak, Jakarta Selatan. Oleh karena itu hasil penelitian tidak dapat digeneralisasi kesimpulannya. Penelitian yang sama dengan penelitian ini pada wilayah lain dapat saja menghasilkan kesimpulan yang berbeda. Untuk memperkaya hasil penelitian, diharapkan penelitian selanjutnya mengambil wilayah penelitian yang lebih luas.

2. Variasi karakteristik yang ada pada diri perempuan wirausaha seperti tingkat pendidikan formal, pengalaman kerja, umur, pendapatan, maupun variasi karakteristik usaha seperti skala usaha dan jenis usaha tidak mendapat perhatian dalam analisis faktor yang mempengaruhi keputusan perempuan berwirausaha di dalam penelitian ini. Untuk itu, penelitian selanjutnya diharapkan dapat memasukan faktor-faktor lain yang belum diteliti dalam penelitian ini.

\section{DAFTAR PUSTAKA}

Aimasari, Nina dan Astri Ghina. 2015. Analisis Faktor-Faktor yang Memotivasi Wanita untuk Menjadi Wirausaha (Studi Pengusaha 
Wanita UMKM di Kota Bandung Tahun 2015). E-Proceeding of Management, Vol. 2 No. 3: 27952799.

Ariefianto, M. Doddy. 2012. Ekonometrika: Esensi dan Aplikasi dengan Menggunakan Eviews. Jakarta: Penerbit Erlangga.

Bandura, Albert. 2001. Social Cognitive Theory: An Agentic Perspective. Annual Reviews of Psychology, Vol. 52: 1-26.

Barani, G. dan Dheepa, T. 2013. Influence of Motives and Its Impact on Women Entrepreneurs of India. Journal of Entrepreneurship and Management, Vol. 2: 24-30.

Nurudin. 2017. Pengaruh Minat dan Lingkungan Keluarga terhadap Keputusan Wanita Muslim
Berwirausaha. SAWWA, Vol. 12 No. 3.

Pristiana, Ulfi, dkk. 2009. Faktor-Faktor yang Mempengaruhi Pengambilan Keputusan Wanita Berwirausaha di Kota Surabaya. Jurnal Riset Ekonomi dan Bisnis, Vol. 9 No. 1: 28-69.

Tambunan, Tulus. 2009. Women Entrepreneurship in Asian Developing Countries: Their Development and Main Constraints. Journal of Development and Agricultural Economics, Vol. 1 No. 2: 27-40. 2012. Usaha Mikro Kecil dan Menengah di Indonesia: Isu-isu Penting. Jakarta: Penerbit LP3ES.

Sugiyono. 2007. Statistika untuk Penelitian. Bandung: CV Alfabeta. 